\title{
Библиотека манастира Каленић и Ризница Епархије шумадијске
}

\author{
Нада Димитријевић \\ Народна библиотека „Радислав Никчевић“, Јагодина \\ naurosevic@yahoo.com
}

\begin{abstract}
Сажетак
У раду је представљена најстарија рукописна и штампана културна заоставштина манастира Каленић. Истраживањем које је спроведено у оквиру заједничког пројекта Архијерејског намесништва беличког и Народне библиотеке у Јагодини,

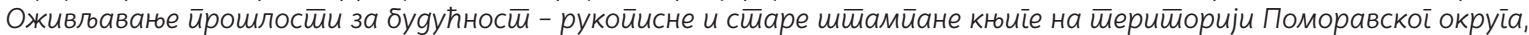
утврђено је да се у манастиру Каленић чува изузетно вредно књижно наслеће Поморавља.

У порти манастира смештена је Библиотека и Ризница Епархије шумадијске. Највреднији део фонда библиотеке манастира Каленић представља Фонд старих богослужбених књига у коме се чува 29 књига које, на основу Закона о старој и реткој библиотечкој грађи, испуњавају услове да се прогласе за културна добра од изузетног или великог значаја.

Ризница Епархије шумадијске чува највредније експонате богослужбених реликвија са простора Епархије шумадијске. Изузетно богатство Ризнице чине рукописне и старе штампане богослужбене књиге.
\end{abstract}

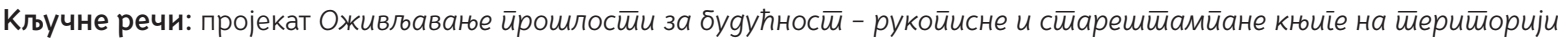
Поморавског окруіа, манастир Каленић, манастирска библиотека, Ризница Епархије шумадијске, рукописне и штампане богослужбене књиге

\section{Увод}

Библиотека манастира Каленић и Ризница Епархије шумадијске у својим фондовима похрањују неке од најзначајнијих рукописних и старих штампаних публикација које спадају у културна добра од изузетног или великог значаја. Оне су биле предмет проучавања у оквиру ширег истраживања спроведеног на територији Поморавског округа. Дугогодишњи заједнички истраживачки рад Народне библиотеке у Јагодини и Архијерејског намесништва беличког, две најзначајније институције у реализацији заштите књиге као покретног културног добра, имао је за циљ очување завичајног и националног културног наслеђа. Резултат сарадње је за-

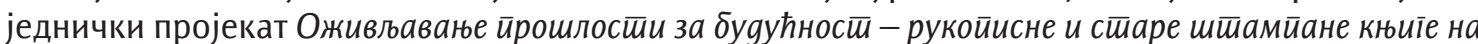

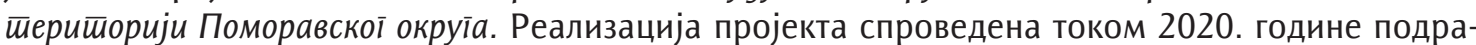
зумевала је истраживање, анализу и библиографску обраду рукописних и најстаријих штампаних књига на територији Поморавског округа. Заокружен процес истраживачког рада је

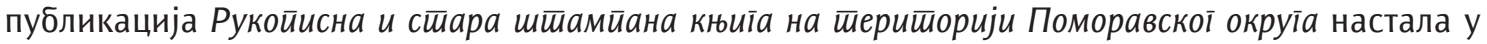
намери да се највредније књижно наслеђе, категорисано као културно добро од изузетног и великог значаја, сачува од заборава и представи широј јавности.

\section{Манастир Каленић}

Храм манастира Каленић посвећен је Ваведењу Пресвете Богородице. Смештен је у подножју Гледићких планина у селу Каленићки Прњавор у општини Рековац. Налази се на територији Епархије шумадијске. Манастир се сврстава међу најзначајније споменике моравске групе и може се слободно рећи да ужива исти углед као и два изузетна владарска маузолеја 
- Манасија и Раваница, који се налазе у његовој близини. Област на пола пута између двеју престоница Београда и Крушевца била је средиште српске државе у време кнеза Лазара и његовог сина Стефана.

У време настанка, у првим деценијама 15. века, била је то једна од најраскошнијих задужбина високих дворских чиновника. Драгоцен извор за реконструкцију историје манастира је запис монаха Герасима (Георгијевића) ${ }^{1}$ на северном зиду припрате на којој је приказан тадашњи владар, деспот Стефан Лазаревић, и породица великаша заслужних за изградњу манастира: „Ктиторъ Петаръ братъ протодовїАросъ, госпожа Милица протодовїАрица, Богдан протодовї̈ръ. Светому храму ктиторъ быстъ благочестивыи Стефанъ деспотъ Лазаревикъ, године 1407."

Познати историјски извори о ктитору Каленића не пружају тачно време изградње манастира. О његовој прошлости у периоду пре пропасти средњовековне државе могуће је судити само на основу информација које су се односиле на дешавања у његовој широј околини. Каленић се, делећи судбину српског народа, тридесетих и четрдесетих година 15. века нашао на удару Турака који су продирали са истока све дубље у Србију. У списима игумана који су током 19. века бележили предања о историји манастира, забележено је да је почетком 17. века Каленић порушен и опљачкан. После два века запустелости, Каленић почетком 18. века обнављају монаси манастира Морача. Нешто више од две деценије касније, гонећи устанике, Турци спаљују манастир. О том немилом догађају сведочи тврдња Милана Ђ. Милићевића да су Турци, за време Кочине крајине 1788. године, запалили манастир Каленић у јагодинској нахији. ${ }^{3}$ Монаси тада, са игуманом Јосифом Вукашиновићем и црквеним богатством, одлазе у фрушкогорски манастир Хопово. По доласку у Хопово, сачињен је инвентар пренетих црквених ствари. Попис који је урађен по налогу карловачког митрополита Стефана Стратимировића сведочи да су, сем богослужбених предмета, каленићки калућери у Хопово пренели и 35 књига. Део тог "Инвентаријума“, под називом „Написаније књига“,садржи податке о 34 руске богослужбене књиге и једној српској, под насловом Књиїа Серйских йросвешиишелеј йравило. ${ }^{4}$ Одлазећи коначно из Хопова, каленићки монаси своје драгоцености враћају у Каленић. ${ }^{5}$

С обзиром на исти богослужбени језик и традиционалну везу српских манастира са православном Русијом, недостатак српских литургијских књига надомешћиван је руским. Из тог разлога, основни део парохијских и манастирских збирки чине руске богослужбене књиге.

У том периоду настају и први инвентари манастирских библиотека. Обнова и попуњавање оскудних манастирских фондова, услед непрекидних ратних страдања и сиромаштва монашких заједница, углавном су зависили од поклона. Дародавци су најугледнији и најимућнији људи из околине манастира. Као приложници се појављују трговци, свештеници и и монаси, о чему сведоче записи на старим каленићким богослужбеним књигама. Они неретко садрже описе важних историјских догађаја или разлоге даривања књига. У њима је исказана молитва

1 Герасим Георгијевић (1831-1839), хроничар, писац, члан каленићког братства и потоњи шабачки епископ.

2 Љубомир Стојановић, Сеиари срӣски зайиси и наййиси (Београд: Српска академија наука и уметности; Народна библиотека Србије; Нови Сад: Матица српска, 1984-1986), 5130 (у даљем тексту ССЗН).

3 Милан Ђ. Милићевић, Манасшир Каленић: заgужбина gесӣошеа Сиеефана Лазаревића: (1405-1427) (Београд: Државна штампарија Краљевине Србије, 1897), 14.

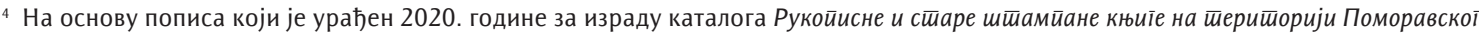
окруїа, утврђено је да се ради о римничком Србљаку из 1761, који се још увек налази у каленићкој библиотеци.

5 Д.[Димитрије] Р.[Руварац],,Калуђери манастира Каленића и других манастира у Хопову“, Срӣски сион бр. 9 (1906): $238-243$.

${ }^{6}$ Нпр. запис у Празничном минеју Божидара Вуковића: „Сія книга Серблякъ купи попъ Симеонъ Попович“. - Нада Димитријевић

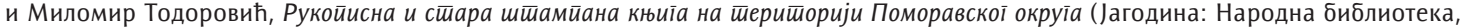
2021), 348

7 „Ф̄ рождества Христова 1172 созданъ бАше монасыръ Ст8деница, храмъ успенїе пресветыА богородицы“ (ССЗН 4926); „еднога кобнога дана 6 априла 1941 године Немци бомбардоваше Београд и ускоро поче II светски рат. Југославија би поробљена од Немаца, Италијана и Бугара и то се продужи до 1944 године а онда када се народ надаше слободи завладаше Комунисти од октобра 1944 године" (запис из Свешиенноі јеванђеља). 
за здравље приложника и његове породице или молитва за вечни помен ближег сродника или родитеља. ${ }^{8}$ Дародавци прилажу по једну књигу, међутим, има и примера када поклањају и више њих. Јеромонах Атанасије се тако помиње у записима на минејима ${ }^{9}$ каленићке библиотеке као дародавац целог минејског комплета. ${ }^{10}$

Јоаким Вујић у својим списима бележи да је Каленић обнављан од 1788. до 1793. године. Ново раздобље за манастир настаје почетком 19. века, када су из сремског манастира Фенек 1815. године у Каленић пренете мошти Стефана Првовенчаног. Тада Каленић постаје једна од највећих националних светиња и место поклоњења српском краљу, све до 1839. године.

„Придите чада послушаите мене страх8 Го(спо)дн8 навчу васъ. Азъ штецъ Саввш сїє написахъ свою рукою въ м. Каленичъ. Знатися када дође святи Краль Стефанъ изъ Немачке перенешенъ у М. Калениће 1815 године и опестъ (!) пренешенъ быстъ у М. Студеницу на своє пострижено место 1839. године. Одъ тада и до данасъ пребіваеть у монастыру Ст8деници кодъ своєга отца Cvмешна мvроточиваго бившагш Краля Сербльмъ именемъ Стефана Неманб прозванагш првогъ и получиша моначескій (!) чинъ одъ Св. Србскаго учителя Архіепіскопа Савве и премениша имена своя и бысть оцу имя Сvмешнъ, а сыну Симонъ земное ц(а)рство оставиша и небесно ц(а)рство насльдници биша". ${ }^{11}$

Манастирски храм са црквом Ваведења Богородице рушен је и обнављан током своје дуге историје од шест векова, делећи судбину свога народа. Манастирски комплекс на коме је 1823-1824. изграђен Милошев конак, изгорео је у пожару 1911, а већ наредне године је обновљен захваљујући тадашњем игуману Никону и јеромонаху Николају (Велимировићу). Рестаурацијом цркве, у периоду 1928-1930. године, манастир поприма изглед који у највећој мери има и данас.

Између два светска рата у Каленићу је често боравио краљ Александар. ${ }^{12}$

После Другог светског рата конак је национализован и физички одвојен од манастира, а 1989. је враћен Каленићу.

„Уочи празника Св. четрдесет мученика у Севастији 1989. године предадосмо кључеве Великог конака каленићског игуманији Маримији - Еп. шумадијски Сава". ${ }^{13}$

Схватајући нужност обнове, епископ шумадијски др Сава Вуковић, у сарадњи са Републичким заводом за заштиту споменика културе 1991. године, покреће иницијативу за обнову манастирског комплекса. После четири године реконструкције, обновљен је Велики и Мали конак. У Малом конаку су две просторије преуређене за Библиотеку и Ризницу Епархије шумадијске. Манастир Каленић тада постаје духовни, културни и просветни центар Поморавља, понос српске средњовековне културе.

\footnotetext{
8 "Сїю светвю книгв, минеи за месецъ октоврїи и прочи единадесат минеевъ отк8пирабъ божїи свещеноеромонах Аөанасие бывшїи пострижникъ морачкїи, себе за здравль и за въчны споменъ, и за споменъ усопшихъ своихъ родителА..." - ССЗН, 4366.

${ }^{9} \mathrm{CC} 3 \mathrm{H}, 3141$.

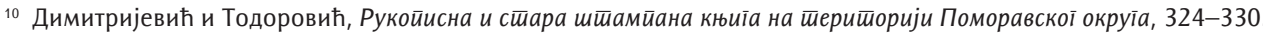

11 Исто, 346-347.

12 Сава Вуковић, „Пред обновљеним конаком манастира Каленић“, у Каленић - gуховно блаїо у новом сјају: обнова манасшира 1991-1997 (Рековац: Туристичка организација општине; Београд: Републички завод за заштиту споменика културе, 1998) 9-10.

13 Димитријевић и Тодоровић, Нав. дело, 357.
} 


\section{Библиотека манастира Каленић}

О прошлости библиотеке у Каленићу сведочи Инвеншеар йокреш̄ної имања Каленићу срезу левачком окружја Jаїоgинскої каленићког игумана Теофила и јеромонаха Мелентија из 1864. године. Посебан део овог инвентара чине „Неименоване црквене књиге“ којих је тада било 232, уз 84 богослужбене књиге. Највероватније је међу пронађеним књигама било и рукописних и старих штампаних, али оне нису посеб̆но означене. У Ннвеншеру се наводи да је манастирска библиотека поседовала још 148 књига разне садржине од којих је било 18 са богослужбеном тематиком. Остале су биле из различитих области људског сазнања, што потврђује да су српски монаси у својој вишевековној историји постојања били главни носиоци културно-просветног живота. ${ }^{14}$

Манастирска библиотека је, на основу плана реконструкције манастирског комплекса након обнове, смештена у једној од просторија Малог конака. Пројектом је планирана израда застакљених полица од храстовине за око 6000 књига. Уређени простор је репрезентативног изгледа и предвиђен је да се користи као читаоница за истраживаче и научне раднике, као и место за одржавање мањих научних скупова..$^{15}$ Библиотека је формирана од монографских и серијских публикација, некњижне грађе прикупљене из манастира и цркава са територије Епархије шумадијске, као и књига различитих дародаваца. Прибављен је и велики број књига од институција, првенствено Српске православне цркве.

Тематски, већину грађе чине црквене литургијске књиге, затим публикације религиозног садржаја, житија светаца и монографије манастира и цркава. Фонд старе штампане богослужбене књиге налази се у саставу манастирске библиотеке. Њега чини 29 књига, 6 српских и 23 руске богослужбене књиге, које на основу Закона о старој и реткој библиотечкој грађи испуњавају услове да се прогласе за културна добра од великог или изузетног значаја. ${ }^{16}$

Најстарија српска штампана књига јесте Србљак (Правила молебнаја свјайих сербских иросвешиитељеј) штампан у Римнику 1761 , на којем се управо и налази запис о преносу моштију Стефана Првовенчаног у манастир Каленић и Студеницу. ${ }^{17}$ Значајно место у манастирској библиотеци заузима Окйоих штампан 1764. године у Грчкоправославној типографији Димитрија Теодосија у Венецији. Захваљујући записима који се налазе у њему, могуће је пратити пут књиге од манастира Студенице преко Сарајева, манастира Јошанице до Каленића и сазнати интересантне и значајне податке о њеним власницима и важним догађајима из живота монаха. ${ }^{18}$ Поједини записи у манастирским књигама сведоче и да је у Каленићу било монаха који су дошли из Студенице. Најстарија руска књига која се налази у фонду манастирске библиотеке је Пролої штампан 1718. године у Москви. Понекад је повезивање књига обухватало и по неколико књига одједном, о томе нам сведоче записи у неколико књига каленићке библиотеке. ${ }^{19}$

Потреба за обнављањем богослужбених књига је у српским манастирима била стална, јер су оне због честог коришћења биле склоне пропадању. Исписивањем свог имена, обновитељ књиге се укључивао у литургијски чин. Записи често, сем имена монаха, садрже и назив књиге,

\footnotetext{
${ }_{14}$ Слободан Милеуснић, „Прошлост и садашњост библиотеке манастира Каленић“, у Каленић-gуховно блаїо у новом сјају: обнова манасйира 1991-1997 (Рековац: Туристичка организација општине; Београд: Републички завод за заштиту споменика културе, 1998), 65-66.

15 Никша Стипчевић, „Библиотека у манастиру Каленић“, у Каленић - gуховно блаїо у новом сјају: обнова манасшира 1991-1997 (Рековац: Туристичка организација општине; Београд: Републички завод за заштиту споменика културе, 1998), 68-69.

16 Фонд старе и ретке библиотечке грађе формиран је по препоруци овлашћеног библиотекара матичне библиотеке, након доделе овлашћења за обављање послова од општег интереса у области старе и ретке библиотечке грађе.

17 Димитријевић и Тодоровић, Нав. дело, 346-347.

18 Исто, 340-341.

19 Исто, 349
} 
као и име манастира којем припада. ${ }^{20}$ Текућу манастирску периодику чине серијске публикације из области религије и православља. Најбројнији су часописи: Каленић, часопис Епархије шумадијске и Гласник, службени лист Српске православне цркве, а осим њих и новине Српске патријаршије Православље.

Некњижну грађу чини углавном ситан документациони материјал у виду различитих брошура, као и мањи број плаката, летака, фотографија и разгледница.

Манастирска библиотека нема дефинисана правила за рад и коришћење фонда. Корисници су најчешће монахиње манастира Каленић и истраживачи са строго конролисаном позајмицом за које је предвиђена читаоница смештена у просторији Библиотеке.

\section{Ризница Епархије шумадијске}

У другој просторији Малог конака налази се Ризница која чува највредније експонате богослужбених реликвија са простора Епархије шумадијске. Значајан део манастирске ризнице чине рукописне и старе штампане богослужбене књиге.

Најстарији рукопис који се налази у Ризници је Минеј служабни за фебруар манасйира Вољавче, ${ }^{21}$ обима 144+(4) листа. Писан је на папиру формата 290x200mm, српскословенским језиком. Писар је користио мастило црне, црвене и златне боје. Књижни блок је оштећен од влаге, посебно почетни и завршни листови на којима се налазе записи писара. Из записа монаха Дионисија, преписивача, може се закључити да је настао у храму Ваведења Пресвете Богородице 1598. године за манастир Равну Реку, посвећен Светој Тројици. Корице су израђене од дрвета пресвученог кожом.

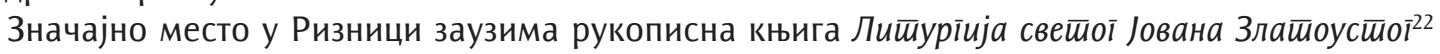
из 17. или 18. века. Писана је на папиру, грчким језиком, веома лепим рукописом за који је коришћено мастило златне, плаве, зелене и љубичасте боје. Литургија има 37 листова, димензија 200x145mm. Кожни повез је украшен златотиском са монограмом IHS и медаљоном на

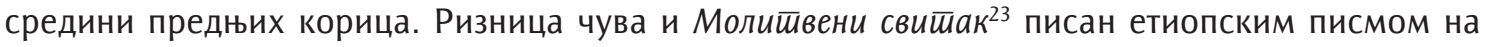
пергаменту у 18. или 19. веку. Свитак је писан црним, црвеним и зеленим мастилом са врло једноставним минијатурама архангела Михаила. Дугачак је два метра, а широк $10 \mathrm{~cm}$.

Међу српским штампаним књижним наслеђем које се чува у Ризници најстарији је Празнични минеј, ${ }^{24}$ штампан у Венецији 1538. године у чувеној штампарији Божидара Вуковића, која је објављивала српске ћириличне књиге богослужбеног и побожног садржаја. Празнични минеј је једно од његових најзначајнијих и најлепших издања које је радио са јерођаконом Мојсијем. На основу записа сазнаје се да је некад припадао Црквеној општини Конатице. Књижни блок је добро очуван. Корице су од дрвета обложене кожом. Ризница чува и Служебник, ${ }^{25}$ штампан 1554. године у штампарији Вићенца Вуковића, који је након очеве смрти наставио штампарску делатност. Тоје поновљено издање Служебника Божидара Вуковића из 1519. године. Повез је кожни. На предњем поткоричном листу налази се печат епископа шумадијског Саве. Ризница епархије шумадијске као изложбени експонат чува и руски Молишевослов, ${ }^{26}$ штампан 1747. године у штампарији манастира Свете Тројице у Черњигову. Веома важно место заузима Свешиеено јеванђеље штампано у Москви 1757. године. Оно има велики број записа који описују важне историјске догађаје од почетка Другог светског рата,

\footnotetext{
20 Жарко Војновић, Срйске манасиииске библиошеке gо краја XVIII века (Панчево: Градска библиотека, 2019$), 131-134$.

21 Димитријевић и Тодоровић, Нав. дело, 303.

22 Исто 302.

23 Исто, 306-307.

24 Исто, 348.

25 Исто, 361.

26 Исто, 333
} 
нарочито о процесу национализације после њега, а записано је и мноштво имена епископа који су на тај начин сведочили о својим посетама манастиру Каленић. Корице Свешиееної јеванђеља су оковане бакром са пет медаљона - Васкрсењем Христовим у средини и четири јеванђелиста у угловима. ${ }^{27}$

\section{Закључак}

Библиотека манастира Каленић и Ризница Епархије шумадијске несумњиво су места очувања вере, традиције и културе, а богослужбене реликвије које се налазе у њима представљају изузетно вредно културно добро за Српску православну цркву и њен народ.

Највећи део богатог српског културног наслеђа нестао је услед неповољних историјских околности које су задесиле Србију. Српски манастири су ипак сачували оно што је Димитрије Богдановић назвао сишара срйска библиошекка.

Проучавањем, анализом и библиографском обрадом рукописних и старих штампаних књига каленићке библиотеке и ризнице представљен је део ове драгоцене књижне збирке. Вредност и разноврсност садржаја каленићке заоставштине пружа широке могућности истраживачима. Значај овог истраживања сагледава се кроз истицање вредности манастирских реликвија и требало би да представља изазов, не само историчарима културе и теолозима, већ и другим научним радницима за потпунију и стручнију анализу рукописних и старих штампаних књига из ове библиотеке.

\section{Литература:}

1. Dimitrijević, Nada i Milomir Todorović. Rukopisna i stara štampana knjiga na teritoriji Pomoravskog okruga. Jagodina: Narodna biblioteka, 2021.

2. Mileusnić, Slobodan. „Prošlost i sadašnjost biblioteke manastira Kalenić“. U Kalenić - duhovno blago u novom sjaju: obnova manastira 1991-1997, 65-66. Rekovac: Turistička organizacija opštine; Beograd: Republički zavod za zaštitu spomenika kulture, 1998.

3. Milićević, Milan Đ. Manastir Kalenić: zadužbina despota Stefana Lazarevića: (1405-1427). Beograd: Državna štamparija Kraljevine Srbije, 1897.

4. R[uvarac], D[imitrije]. „Kaluđeri manastira Kalenića i drugih manastira u Hopovu“. Srpski sion br. 9 (1906): 238-243.

5. Stipčević, Nikša. „Biblioteka u manastiru Kalenić". U Kalenić - duhovno blago u novom sjaju: obnova manastira 1991-1997, 68-69. Rekovac: Turistička organizacia opštine; Beograd: Republički zavod za zaštitu spomenika kulture, 1998.

6. Stojanović, Ljubomir. Stari srpski zapisi i natpisi. Beograd: Srpska akademija nauka i umetnosti; Narodna biblioteka Srbije; Novi Sad: Matica srpska, 1984-1986.

7. Vojnović, Žarko. Srpske manastirske biblioteke do kraja XVIII veka. Pančevo: Gradska biblioteka, 2019.

8. Vuković, Sava. „Pred obnovljenim konakom manastira Kalenić". U Kalenić - duhovno blago u novom sjaju: obnova manastira 1991-1997, 9-10. Rekovac: Turistička organizacija opštine; Beograd: Republički zavod za zaštitu spomenika kulture, 1998.

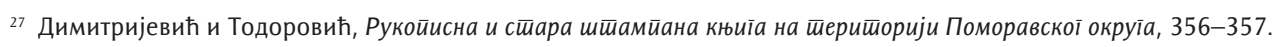




\section{Treasury of the Eparchy of Šumadija and the Library of the Kalenić Monastery}

\section{Summary}

Despite centuries of unfavorable historical changes in the Balkans, when Serbian monasteries and churches were being destroyed and burnt, manuscripts and printed books were preserved in monastic and church libraries. They are a real treasure trove of Serbian cultural heritage, and these libraries represent an exceptional part of the spiritual, cultural, historical, and national wealth of Serbia

The joint desire to protect books as a movable cultural good has led to the cooperation of the Public Library in Jagodina and the Archdiocese of Belica. The joint project of these two institutions named Reviving the Past for the Future - Manuscripts and Old Printed Books on the Territory of the Pomoraulje District was implemented in 2020 and included research, analysis, and bibliographic processing of manuscripts and the oldest printed books on the territory of the Pomoravlje District. The result of the research is the publication named Manuscripts and Old Printed Books on the Territory of the Pomoraulje District.

During the realization of the project, it was found that the extremely valuable literary heritage related to the territory of Pomoravlje is preserved in the Kalenić Monastery. The Treasury of the Eparchy of Šumadija and the library are located in the monastery courtyard. The treasury keeps the most valuable manuscripts and the oldest printed liturgical books from the territory of the Eparchy of Šumadija. The most valuable part of the Kalenić Monastery library is the fund of old liturgical books, including 29 books that meet the conditions to be declared cultural goods of exceptional or great importance, based on the Law on Old and Rare Library Materials.

After the research, analysis, and bibliographic processing of manuscripts and old printed books found in the Kalenić Monastery, a part of this valuable book collection was presented. The value and diversity of the content of the Kalenić legacy provide wide opportunities for researchers and scientists from various fields.

Keywords: project Reviving the Past for the Future - Manuscripts and Old Printed Books on the Territory of the Pomoraulje District, Kalenić Monastery, monastic libraries, Treasury of the Eparchy of Šumadija, manuscript, liturgical books, printed liturgical books 